\title{
Comparative Study Of Structure Response Isolated Base And Not Isolated Base on IHF School Cimanggis
}

\author{
Agyanata Tua Munthe and M. Iksan \\ Faculty of Engineering, University Mercu Buana Jakarta, Indonesia \\ Agyanata.umb@gmail.com, Iksanmuhamad59@gmail.com
}

\begin{abstract}
Along with technological developments in the field of civil engineering, various systems are used to reduce the impact of earthquakes on the structure. One system that has long been developed is a passive prevention system consisting of seismic isolation. Buildings that use seismic dumper are expected to fail structure when an earthquake occurs. This study discusses the comparison of internal forces in buildings using base isolation and without base isolation. The building which is the case study is the Indonesian Heritage Foundation school building in Cimanggis. The analysis uses the 2016 ETABS program. Earthquake analysis uses the Spectrum Response method. From the research results, it is known that the building which was installed with an insulator shakes the structure to 1,344 seconds. The vibration period of the structure increased $41 \%$ from the vibration period of the structure which still used a fixed base of 0.796 seconds. Seen from the intersection between floors the maximum direction of X can be reduced by $15.4 \%$ by installing an insulator. The same thing happened to the maximum inter-floor deviation for the $\mathrm{Y}$ direction deviation is muted by $27.75 \%$. Base isolation installation reduces the moment in a column by $36 \%$ in the earthquake $\mathrm{X}$ direction and $61 \%$ in the earthquake $\mathrm{Y}$ direction. For column shear force is reduced by $58 \%$ in the earthquake $\mathrm{X}$ direction and $75 \%$ in the earthquake $\mathrm{Y}$ direction. Base isolation can reduce basic shear force in buildings by $24.49 \%$ in the $\mathrm{X}$ direction of the building and $22.24 \%$ in the $\mathrm{Y}$ direction.
\end{abstract}

Keywords: Base Isolation, ETABS 2016, Spectrum Response, Earthquake Force.

\section{Introduction}

The ideas behind the concept of base isolation are very simple, namely how to separate the building base related to the ground and the structure of the upper structure, so that the movement of the soil is not directly transferred to the upper structure. The concept of seismic isolation is a significant development in earthquake engineering in the last 20 years. This system has been widely used by countries that have a high risk of earthquakes such as Japan, Italy, the United States, Turkey, China, Taiwan, and Indonesia. This system will separate the building or structure from a relatively small horizontal component between the upper building and the foundation. As a result of the acceleration of the earthquake that works on the building becomes smaller. The first vibrating range of buildings only causes lateral deformation in the isolator system, while the upper part will behave as rigid body motion. The higher vibrational variations that cause deformation in the structure are orthogonal to the first variance and ground motion so that these vibrational variations do not participate in the structural response, or in other words earthquake energy is not dissipated to the building structure (Neim and Kelly, 1999 ).

In a strong earthquake, an insulator with relatively small horizontal stiffness will cause the natural period of the building to be larger, (generally between 2 - 3.5 seconds). In this period the earthquake acceleration was relatively small, especially in hard ground. Connecting with the insulator will reduce acceleration in building structures. However, the reverse will cause an increase in displacement in the building. To limit displacement to the acceptable limits, the isolation system is also equipped with elements capable of diminishing energy. Apart from that, the isolation system also has the ability to return to its original position after the appearance of a cynical movement. Whereas in small earthquakes or due to wind the horizontal stiffness of the insulator system must be adequate, so as not to cause vibrations that cause the discomfort of its inhabitants (Kelly, 2001)

\section{Metodholgy}

The research method used will use the analysis method in building structure modeling where the plan will use Base Isolation with reference to applicable regulations such as the Indonesian National Standard (SNI).

This research method uses the case study analysis method. The case study method is in the form of re-planning with a model made according to the condition of the building. The research method used has stages of input, 


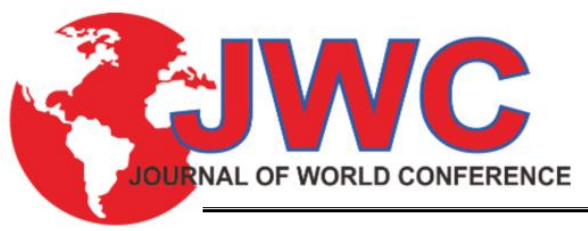

VOLUME 2 NUMBER 2 | MARCH 2020

Available online at http://proceedings.worldconference.id.

ISSN: 2656-1174 (online)

analysis, and output. At the input, stage will be explained about the structure geometry, dimensions, and specifications of structural elements, the determination of the burden of working with 3-dimensional modeling. The stages of analysis include structural modeling using the 2016 ETABS software The final stage is the output stage which discusses the comparison of buildings without Base isolation and buildings with Base isolation.

\section{Structure Geomethry}

The building that will be planned using the Base isolation system has the following planning data:

a. Building Name : Gedung Indonesia Heritage Foundation

b. Location : St. Mochamad Thohir, Kecamatan Tapos, Depok

c. Building Function : School

d. Jenis Tanah : Medium Soil

e. Jumlah Lantai : 6 Floor

f. Height between Floor

Basement Floor $1 \quad: 3,5$ meter

Floor 1 Floor $2 \quad: 4.5$ meter

Floor 2 Roof Floor $\quad: 3.7$ meter

g. Total Height : 15.6 meter

h. Structure System : Base Isolation

i. Material Specification :

Concrete Quality used

- Column and Beam

- Slab

: f'c $30 \mathrm{MPa}$

Rebar quality used

: f'c $30 \mathrm{MPa}$

- Column Rebar (D16 \& D13) : fy $420 \mathrm{MPa}$

- Beam Rebar(D22, D19 \& D16) : fy $420 \mathrm{MPa}$

- Slab Rebar (D10) : fy $420 \mathrm{MPa}$

j. Earthquake Load

\begin{tabular}{|c|c|c|c|c|c|}
\hline $\mathrm{S}_{\mathrm{s}}$ & 0.768 & $\mathrm{~F}_{\mathrm{a}}$ & 1,193 & $\mathrm{~S}_{\mathrm{DS}}$ & $0.61 \mathrm{~g}$ \\
\hline $\mathrm{S}_{1}$ & 0,295 & $\mathrm{~F}_{\mathrm{v}}$ & 1,756 & $\mathrm{~S}_{\mathrm{D} 1}$ & $0.377 \mathrm{~g}$ \\
\hline
\end{tabular}

The design category is determined by value SDS dan SD1 that is type D

- $\quad$ Vibration period, $\mathrm{T} 0=0.512 \mathrm{~s}$ dan $\mathrm{Ts}=0.512 \mathrm{~s}$

k. Design calculation

\section{Analysis}

A. Design calculation

$\checkmark \quad$ The value of the fundamental period $\Rightarrow$ Ta $=0.6627 \mathrm{~s} \&$ Tmaks $=0.9278 \mathrm{~s}$

$\checkmark \quad$ Periode The period value of Etabs $=>\mathrm{Tx}=0.796 \mathrm{~s} \& \mathrm{Ty}=0.754$ second (OK)

B. Base Shear Factored

\begin{tabular}{|c|c|c|c|c|c|}
\hline \multicolumn{2}{|l|}{ Earthquake Load } & Fx $(\mathrm{kN})$ & Fy $(\mathrm{kN})$ & $85 \%$ Static & $\begin{array}{c}\mathrm{V}_{\text {dinamic }}>0.85 \\
\mathrm{~V}_{\text {static }}\end{array}$ \\
\hline Static & Ex & 36478.4 & & 31006.6 & OK \\
\hline & Ey & & 36478.4 & 31006.6 & OK \\
\hline Dinamic & RSx & 33786.4 & & & \\
\hline & Rsy & & 33544.03 & & \\
\hline
\end{tabular}

\section{Story Drift}

The type of structure is the SRPMK structure so the deviation between permit floors $\Delta$ a risk category II then uses the formula :

$\Delta \mathrm{a} \quad=0.010 \mathrm{x} \mathrm{hx}$ 


\begin{tabular}{|c|c|c|c|c|c|c|}
\hline $\begin{array}{l}\text { TABLE: } \\
\text { Story } \\
\text { Response }\end{array}$ & & & & & & \\
\hline Story & $\begin{array}{l}\text { Elevation } \\
\quad(\mathrm{m})\end{array}$ & Location & $\begin{array}{l}\text { X-Dir } \\
(\mathrm{mm})\end{array}$ & $\begin{array}{l}\text { Y-Dir } \\
(\mathrm{mm})\end{array}$ & \multicolumn{2}{|c|}{$0.010 \mathrm{x}$ hy } \\
\hline FLOOR 5 & 19.1 & Top & 6.063692 & 5.998939 & ok & ok \\
\hline FLOOR 4 & 15.4 & Top & 5.296217 & 5.249467 & ok & ok \\
\hline FLOOR 3 & 11.7 & Top & 4.131247 & 4.100812 & ok & ok \\
\hline FLOOR 2 & 8 & Top & 2.621681 & 2.605487 & ok & ok \\
\hline FLOOR 1 & 3.5 & Top & 0.68633 & 0.679103 & ok & ok \\
\hline BASE & 0 & Top & 0 & 0 & ok & ok \\
\hline
\end{tabular}

D. Dimension of base isolation

After analysis of buildings with fixed base, conditions are calculated and meet the requirements. Then the results of the force analysis in the structure of the building without base isolation data are taken in the form of the largest axial force of the building column for the purpose of planning the base isolation dimensions suitable for a 6 -story building.

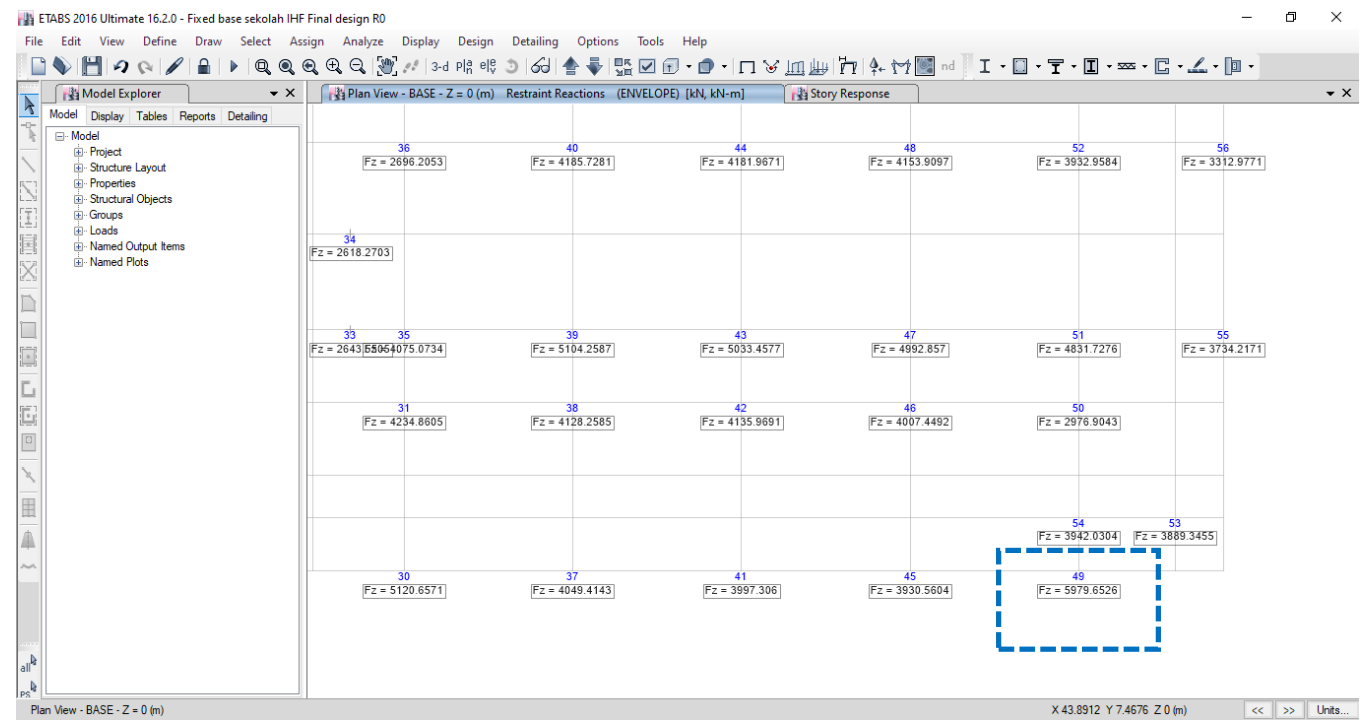

Source: Data in research, 2020

For the planning of the base isolator dimensions the axial force of the largest column is taken with a value of $5979652.6 \mathrm{~N}$ and a total structural weight (Wt) $810822590 \mathrm{~N}$

Internal forces in building structures

- Maximum Axial force on bearing (W) $=5979652.6 \mathrm{~N}$

- Total weight of structure (Wt) $\quad=810822590 \mathrm{~N}$

- Amount of bearing $\quad=56 \mathrm{pcs}$

Specification bearing used :

- Shear Modulus (G)

- Damping $(\beta)$

- Asumption period (Td)

- Max Shear strain $(\gamma)$

- Acceleration of gravity $(\mathrm{g})$

$$
\begin{aligned}
& =0.392 \mathrm{Mpa} \\
& =0.170 \quad \begin{array}{l} 
\\
=1 \quad
\end{array} \quad=9.71 \mathrm{sec} \\
& \quad=91 \mathrm{~m} / \mathrm{s}^{2}
\end{aligned}
$$


Horizontal stiffness $\left(K_{H}\right)$

$K_{H}=\frac{W}{g} x\left(\frac{2 \pi}{T_{D}}\right)^{2}$

$K_{H}=\frac{5979652.6}{9.81} x\left(\frac{2 \pi}{1.71}\right)^{2}$

$K_{H}=8221177.27 \mathrm{~N} / \mathrm{m}$

\section{$>$ Design Desplacement $\left(D_{D}\right)$}

$B_{D}=1.2$

$S_{M 1}=0.64$

$D_{D}=\frac{g}{4 \pi^{2}} \times \frac{C_{V D} x T_{D}}{B_{D}}$

$D_{D}=\frac{9.81}{4 \pi^{2}} \times \frac{0.64 \times 1.71}{1.2}$

$D_{D}=0.227 \mathrm{~m}$

determine diameter of the bearing

$$
\begin{aligned}
& T_{r}=\frac{D_{D}}{\gamma} \\
& T_{r}=\frac{0.227}{1} \\
& T_{r}=0.227 \mathrm{~m}
\end{aligned}
$$

With the thick rubber you can get a temporary cushion surface area :

$A=\frac{K_{H} x T_{r}}{G}$

$A=\frac{8221177.27 \times 0.227}{0.3 E 08}$

$A=0.475 \mathrm{~m}^{2}$

So that the bearing diameter is obtained:

$\emptyset=\sqrt{\frac{4 A}{\pi}}$

$\varnothing=\sqrt{\frac{4 \times 0.475}{\pi}}$

$\emptyset=0.7785 m$

Then the bearing surface area is:

$$
\begin{aligned}
A & =\frac{\pi \emptyset^{2}}{4} \\
A & =\frac{\pi \emptyset^{2}}{4} \\
A & =\frac{\pi x(0.7785)^{2}}{4}
\end{aligned}
$$


$A=0.475 \mathrm{~m}^{2}$

With the bearing surface area obtained the new horizontal stiffness value is :

$K_{H b}=\frac{G \times A}{T_{r}}$

$K_{H b}=\frac{0.3 E 08 \times 0.475}{0.227}$

$K_{H b}=8221177.27 \mathrm{~N} / \mathrm{m}$

$K_{\text {Htotal }}=56 \times K_{H b}$

$K_{\text {Htotal }}=460385927.1 \mathrm{~N} / \mathrm{m}$

\section{Determine of frekuensi $(\omega)$ and Period $(T)$}

$\omega^{2}=\frac{K_{\text {Hotal }} \times g}{W}$

$\omega^{2}=\frac{460385927.1 \times 9.81}{W}$

$\omega=2.36 \mathrm{rad} / \mathrm{sec}$

$T=\frac{2 \pi}{\omega}$

$T=\frac{2 \pi}{2.36}$

$T=2.661 \mathrm{sec}>1.71 \mathrm{sec}$

\section{$>$ Shape Factor $\left(S_{1}\right)$}

Assumed vertical frequency $(\mathrm{Fv})=10 \mathrm{~Hz}$

Then the horizontal frequency:

$F h=\frac{1}{T}$

$F h=0.3758 \mathrm{~Hz}$

shape Factor $\left(S_{1}\right)$

$S=\frac{1}{\sqrt{6}} x \frac{F v}{F h}$

$S=\frac{1}{\sqrt{6}} \times \frac{10}{0.3758}$

$S=10.86304091$

Determine the modulus of compression (Ec) Sliding modulus with a small strain occurs when $\gamma=20 \%$, where the bearing properties are :

$G_{0,2}=1.4 \mathrm{Mpa}$

$K \quad=2000 \mathrm{Mpa}$ 
Then the compression modulus is:

$E c=\frac{6 G S^{2} K}{6 G S^{2}+K}$

$E c=662765295.4 \mathrm{~N} / \mathrm{m}^{2}$

$>$ Vertical stifness $(\mathrm{Kv})$

$K v=\frac{E c x A}{T_{r}}$

$K v=\frac{662765295.4 \times 0.622}{0.227}$

$K v=1389977291 \mathrm{~N} / \mathrm{m}$

$>$ Determine thickness of layer

$t=\frac{\emptyset}{4 S}$

$t=\frac{0.7785}{4 \times 10.863}$

$t=0.0179$

Layer amount (n)

$n=\frac{T_{r}}{t}$

$n=\frac{0.227}{0.0179}$

$n=12.66177351$

Then the thickness of the new rubber is:

$T_{\text {rbaru }}=n x t$

$T_{\text {rbaru }}=12.66177351 \times 0.0179$

$T_{\text {rbaru }}=0.2268 \mathrm{~m}$

\section{Determine dimension of bearing}

Bearing height (h)

$h=2 \times t_{\text {pelat }}+n t+\left((n-1) x t_{\text {shim }}\right.$

$h=2 \times 0.04+0.2268+((13-1) \times 0.0031$

$h=0.295 m$

shims diameter $\left(\emptyset_{s}\right)$ are :

$\emptyset_{s}=\emptyset-\left(2 x t_{\text {cover }}\right)$

$\emptyset_{s}=0.7785-(2 x 0.005)$

$\emptyset_{s}=0.7685 \mathrm{~m}$ 


\section{Determine value of buckling loads}

$I=\frac{\pi}{4}\left(\frac{\emptyset_{s}}{R w}\right)$

$I=\frac{\pi}{4}\left(\frac{0.7685}{2}\right)$

$I=0.0171 \mathrm{~m}^{4}$

Then the surface area of the shims is :

$A s=\frac{\pi \emptyset_{S}^{2}}{4}$

$A s=\frac{\pi x(0.7685)^{2}}{4}$

$A s=0.464 m^{2}$

Then the buckling load value of the bearing is :

$P_{\text {crit }}=\frac{\pi}{t r} \sqrt{\frac{E c I}{3}} G_{0.2} A s$

$P_{\text {crit }}=\frac{\pi}{0.2268} \sqrt{\frac{662765295.4 \times 0.0171}{3}} \times 1400000 \times 0.464$

$P_{\text {crit }}=21682940.13 \mathrm{~N}$

The value of the safety factor to prevent buckling is :

$$
\begin{aligned}
& S F=\frac{P_{\text {crit }}}{W} \\
& S F=\frac{21682940.13}{5979652.6} \\
& S F=3.626>3
\end{aligned}
$$

\section{$>$ Determine of rollout displacement}

$$
\begin{aligned}
& D_{\text {max }}=\frac{\emptyset}{1+\frac{K_{H b} h}{W}} \\
& D_{\text {max }}=1.184 \mathrm{~m}
\end{aligned}
$$

From the above calculation we get the dimensions of Base isolator as follows:

- $\quad$ Bearing height(h)

$$
=0.295 \mathrm{~m}
$$

- Bearing Diameter $(\varnothing)=0.7785 \mathrm{~m}$

- $\quad$ shims Diamater $\left(\emptyset_{S}\right)=0.7685 \mathrm{~m}$ 
- layer amount(n)

$=13$ Layer

- $\operatorname{shims}$ amount $\left(n_{S}\right) \quad=12$ Layer

- $\quad$ shims thickness $\left(t_{S}\right)=0.0031 \mathrm{~m}$

- $\quad$ Rubber thickness $\left(t_{r}\right)=0.0179 \mathrm{~m}$

- cover plate thickness $\left(t_{p}\right) \quad=0.028 \mathrm{~m}$

Based on the calculation using the design step, obtained property dimensions from the Bridgestone-Seismic isolation product line-up catalog. So Base isolation suitable for use in IHF school buildings is High damping rubber bearing type HH080X4S. The following physical dimensions of HDRB type HH080X4S:

- $\quad$ Diameter of bearing $(\varnothing) \quad=0.800 \mathrm{~m}$

- $\quad=0.422 \mathrm{~m}$

- $\quad$ Total Weight $\quad=1.21$ ton

- Total Weight $\quad=11.9 \mathrm{KN}$

- Shear modulus $\quad=0.392 \mathrm{~N} / \mathrm{mm}^{2}$

\section{Result}

1. Dimension of Base Isolation

Based on the calculation using the design step, obtained property dimensions from the Bridgestone-Seismic isolation product line-up catalog. So Base isolation suitable for use in IHF school buildings is High damping rubber bearing type HH080X4S. The following physical dimensions are HDRB type HH080X4S:

Bearing Height $=0.422 \mathrm{~m}$

Total Weight $=1.21$ ton

Total Weight $=11.9 \mathrm{KN}$

Shear modulus

$$
=0.392 \mathrm{~N} / \mathrm{mm}^{2}
$$

2. Comparative Analysis

Buildings that have been modeled and are running on Etabs 2016 taking into account earthquake loads. Furthermore, it will be seen how much the ratio of deviation, internal forces, and base shear that occurs between building structures with Fixed Base conditions and Isolated Base condition structures due to earthquake forces.

a. Period of Structural Vibration

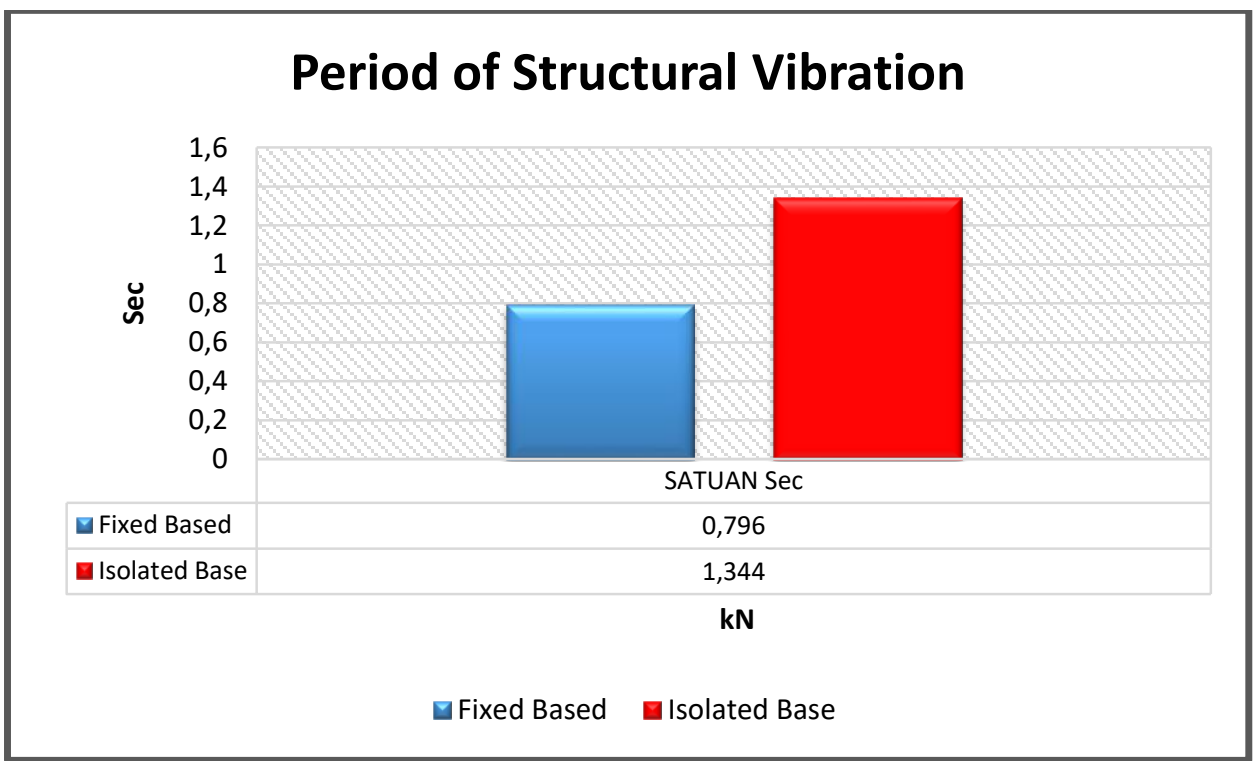

Source: Data in research, 2020 
b. Displacement

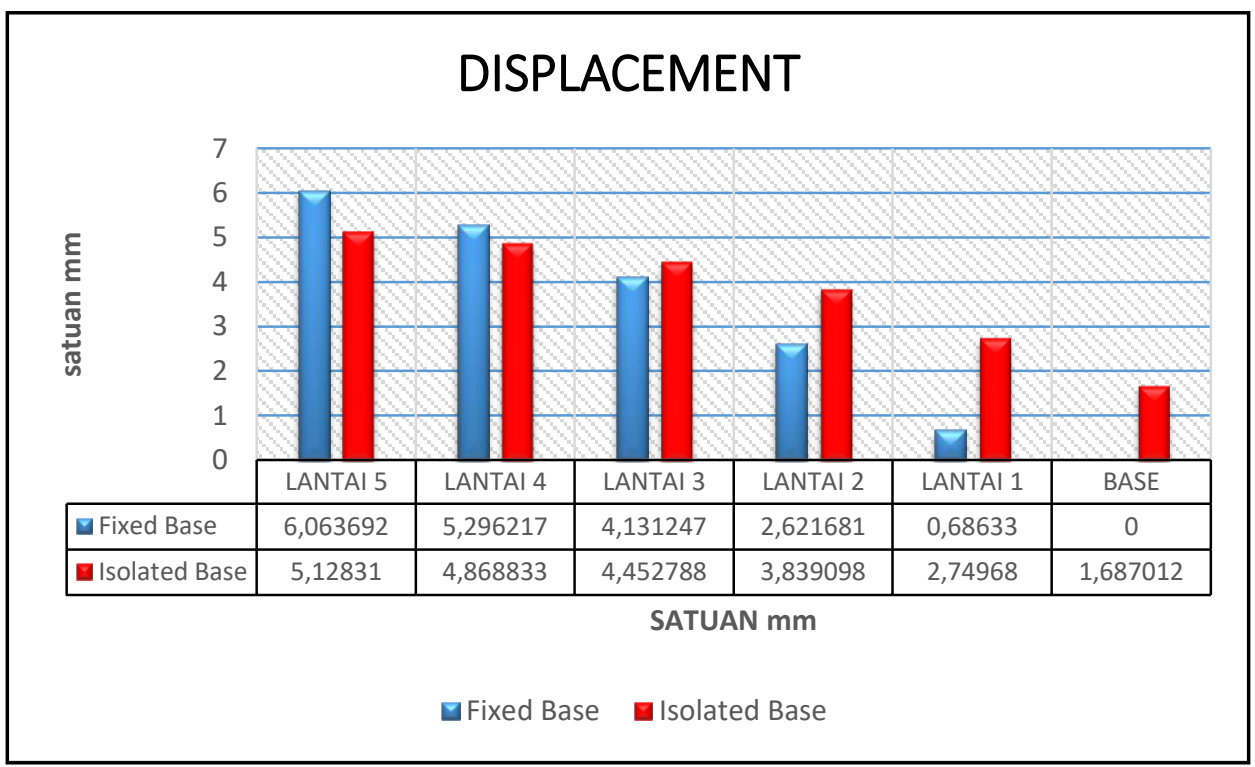

Source: Data in research, 2020

c. Internal Force in column C1 As I-4

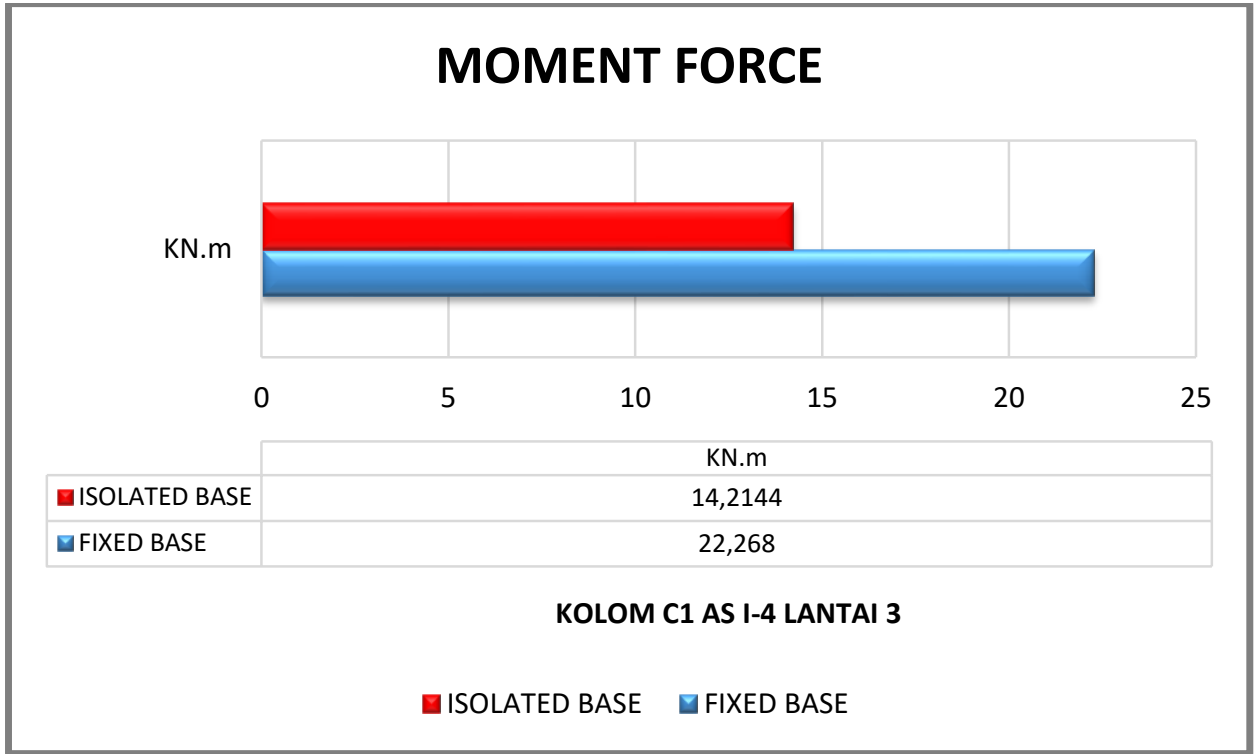

Source: Data in research, 2020 


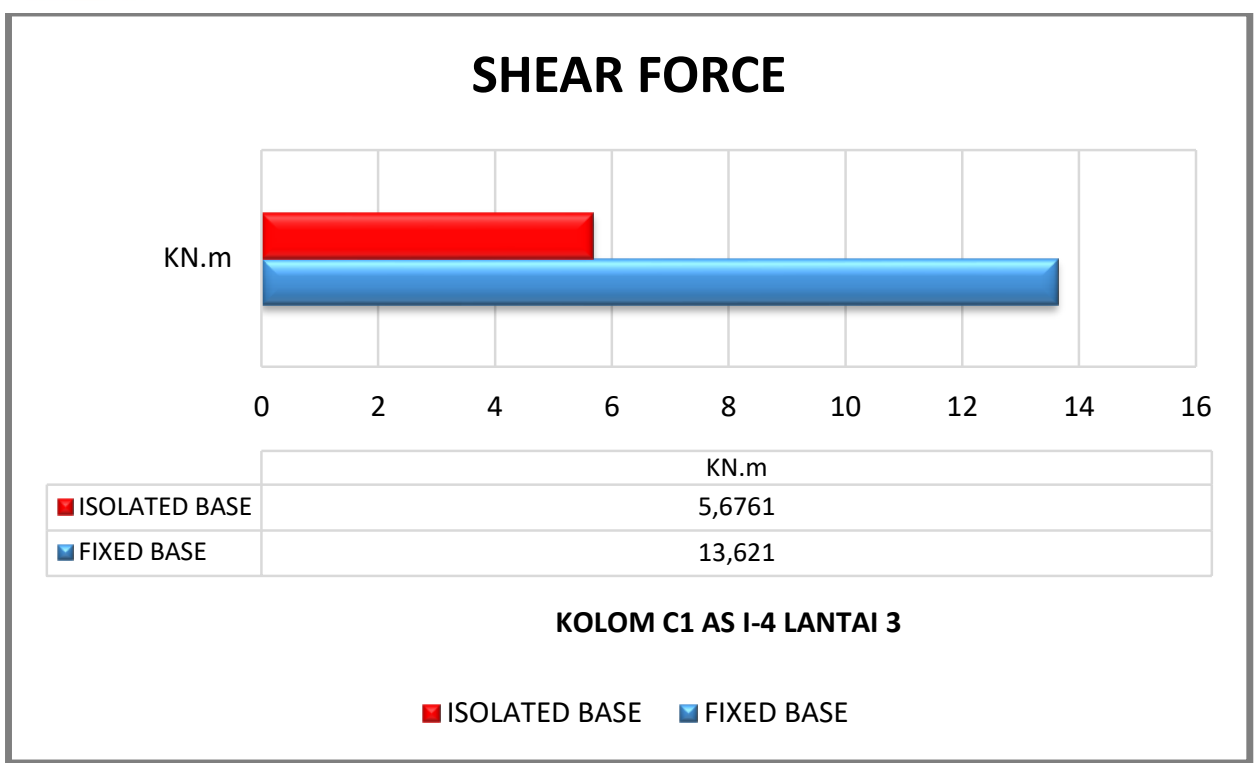

Source: Data in research, 2020

d. Internal Force in Beam G-4 $2^{\text {nd }}$ Floor

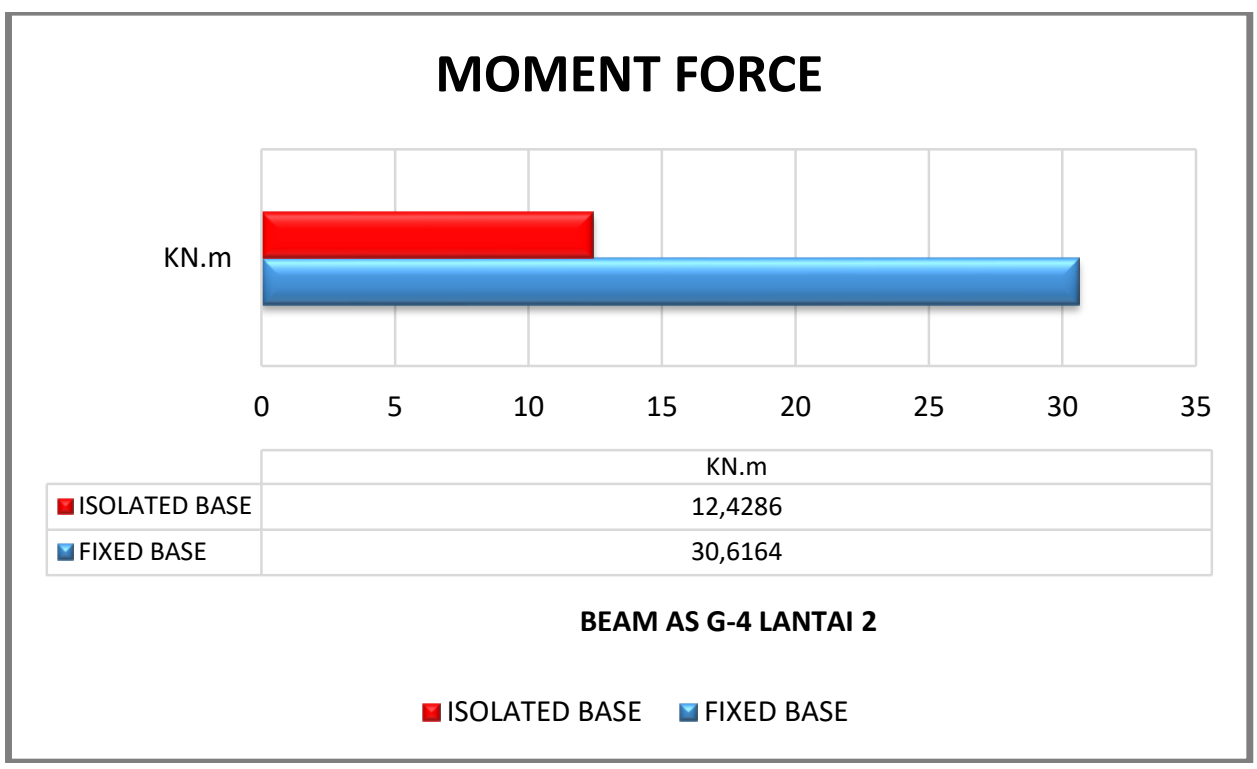

Source: Data in research, 2020 


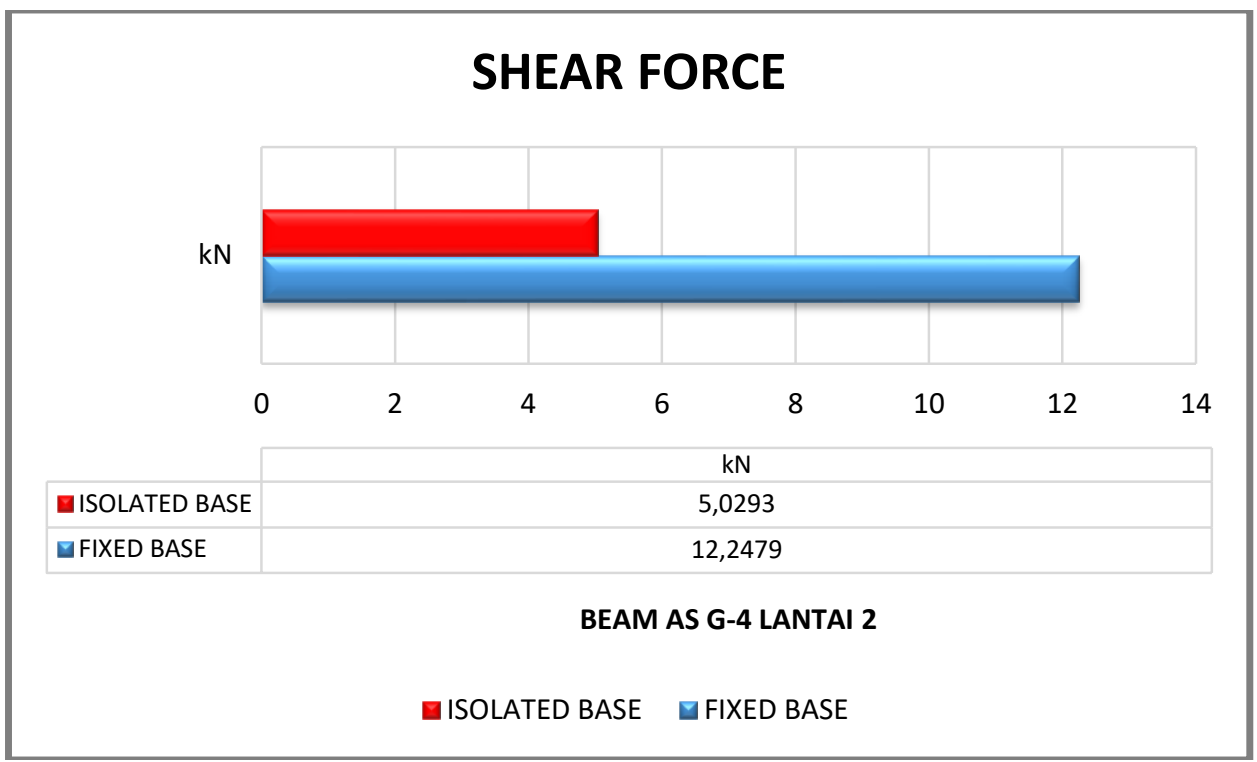

Source: Data in research, 2020

e. Base Shear Force

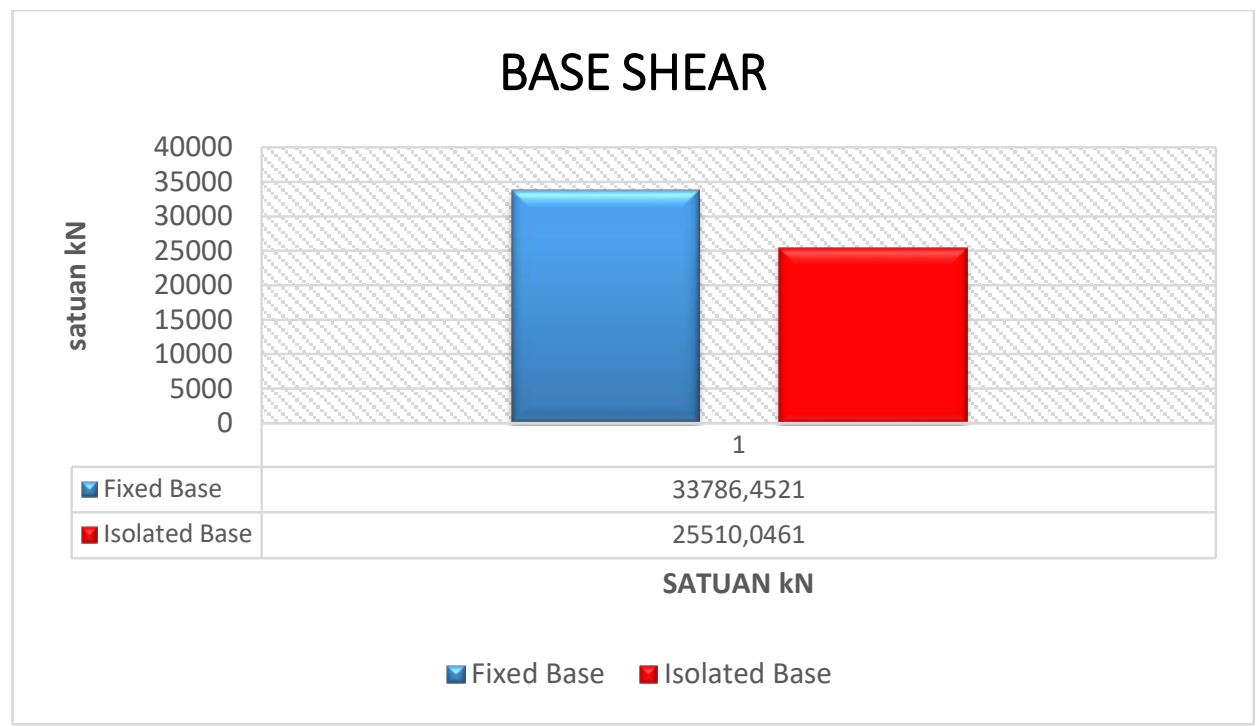

Source: Data in research, 2020

\section{Conclusion}

Based on the purpose of writing this thesis and based on the results of structural analysis obtained using ETABS 2016, the authors can draw the following conclusions :

1. Based on the calculation results of the isolator design, the dimensions of the HDRB isolator from the Bridgestone-Seismic isolation product line-up are obtained, namely the HH080X4S type with specifications:

Diameter $(\varnothing) \quad=0.800 \mathrm{~m}$

Bearing Height $\quad=0.422 \mathrm{~m}$ 
Total Weight $\quad=1.21$ ton

Total Weight $\quad=11.9 \mathrm{KN}$

Shear modulus $\quad=0.392 \mathrm{~N} / \mathbf{m m}^{\mathbf{2}}$

2. The building which was installed with an insulator shakes its structure to 1,344 seconds. The vibration period of the structure increased $41 \%$ from the vibration period of the structure which still used a fixed base of 0.796 seconds.

3. The maximum inter-floor deviation of $X$ direction can be reduced by $15.4 \%$ by installing an insulator. The same thing happened to the maximum inter-floor deviation for the Y direction deviation is muted by $27.75 \%$.

4. Installation of base isoalation can reduce the moment in the column by $36 \%$ in the $\mathrm{X}$ direction earthquake and $61 \%$ in the $\mathrm{Y}$ direction earthquake. For the reduced shear force of the column by $58 \%$ in the $\mathrm{X}$ direction earthquake and $75 \%$ in the $\mathrm{Y}$ direction earthquake.

5. Installation of base isoalation can reduce the moment on the beam by $59 \%$ in the X-direction earthquake and $52 \%$ in the $\mathrm{Y}$ direction earthquake. For the column shear force is reduced by $59 \%$ in the X-direction earthquake and $53 \%$ in the Y direction earthquake.

6. The installation of base isolation in the IHF school building can reduce the basic shear force in buildings by $24.49 \%$ in the $\mathrm{X}$ direction of the building and $22.24 \%$ in the $\mathrm{Y}$ direction.

\section{Reference}

[1] Alharis, Mohamad (2012). Analisa pengaruh Seismic Isolation terhadap perilaku lateral pondasi pada Gedung Dinas Prasarana jalan Tata ruang dan Pemukiman Sumatera Barat. Universitas Indonesia

[2] Andrian, wiki; Faimun; Wahyuni, endah. (2017). Evaluasi Kinerja Gedung Menggunakan Base Isolation Tipe High Damping Rubber Bearing (HDRB) Pada modifikasi Gedung J-Tos Jogjakarta Dengan Perencanaan Analisis Pushover. Institut Teknologi Sepuluh Nopember.

[3] Angelis, Fabio De; Cancellara, Donato. (2018). Dynamic analysis and vulnerability reduction of asymmetric structures:Fixed base vs base isolated system. Composite Structures 219 : 203-220.

[4] Anonim. (2019) www.id.wikipedia.org

[5] Budiono, Bambang. Setiawan, Andri. (2014). Studi Komparasi Sistem Isolasi Dasar High-Damping Rubber Bearing dan Friction Pendulum System pada Bangunan Beton Bertulang. Institut Teknologi bandung.

[6] Habieb, Basshofi Ahmad; Valente, Marco; Milani, Gabriele. (2019). Effectiveness of different base isolation systems for seismic protection Numerical insights into an existing masonry bell tower. Soil Dynamics and Earthquake Engineering $125: 105752$.

[7] Ismail, Febrin Anas. (2012). Pengaruh Penggunaan Seismic Base Isolation System Terhadap Respon Struktur Gedung Hotel Ibis Padang. Jurnal Rekayasa Sipil, Volume 8 No.1, Universitas Andalas.

[8] Kelly, T. (2001). Base Isolation of Structures : Design Guidelines. Wellington, New Zealand: Holmes Consulting Group

[9] Khan, Bilal L.; Azeem, Muhammad; Usman, Muhammad; Farooq, Syed H.; Hanif, Asad. (2019). Effect of near and far Field Earthquakes on performance of various base isolation systems. Procedia Structural Integrity $18: 108-118$.

[10] Mazza, Fabio; Labernada, Rodolfo. (2018). Effects of nonlinear modelling of the base-isolation system on the seismic analysis of r.c. buildings Effects of nonlinear modelling of the base-isolation system on the seismic analysis of r.c. buildings. Procedia Structural Integrity $11: 226-233$.

[11] Mc Cormac, J.C. (2002). Desain Beton Bertulang Jilid 2. Jakarta : Erlangga

[12] Muliadi; Ihsan, M. Kabir. (2009). Analisis perioda bangunan dinding geser dengan Base isolator akibat gaya gempa. Universitas Malikussaleh.

[13] SNI 2847 : 2013. (2013). Persyaratan Beton Struktural untuk Bangunan Gedung. Jakarta, Indonesia : Badan Standardisasi Nasional

[14] SNI 1726 : 2012. (2013) Tata cara Perencanaan Ketahanan Gempa untuk Struktur Bangunan $15 . \quad$ Gedung 


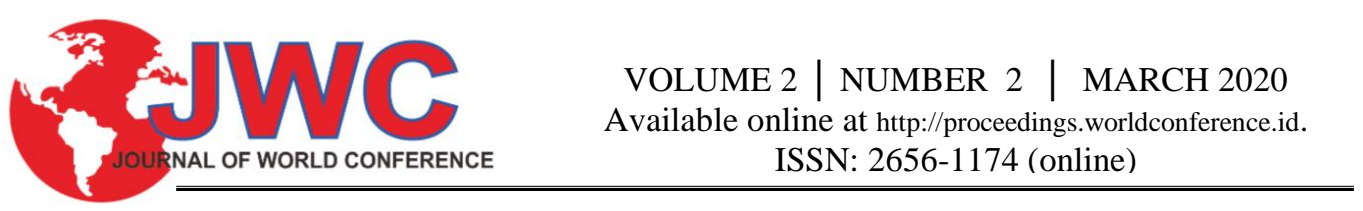

dan Non Gedung. Jakarta, Indonesia : Badan Standardisasi Indonesia

[15] SNI 1727 : 2013. (2013). Tata Cara Perencanaan Pembebanan untuk Rumah dan Gedung. Jakarta, Indonesia: Badan Standardisasi Nasional.Teruna, Daniel Rumbi. (2005). Analisis Respon Bangunan dengan Base Isolator akibat Gaya Gempa. University of Sumatera Utara.

[16] Villaverde, R. (2009). Fundamental Concepts of Earthquake Engineering. Boca Raton.

\section{Biographies}

Agyanata Tua Munthe was born in March 21, 1981. After graduation his highschool education at BPK Penabur senior high school in Bandar Lampung, continued his civil engineering education at Atmajaya University, Special Region of Yogyakarta in 2004. He obtained his Master's degree in civil engineering in 2006 at University of Gadjah Mada, Special Region of Yogyakarta. Currentlt active as lecturer at Mercu Buana University, Jakarta as a lecturer with a concentration in structure and currently active as a project manager handling several construction project.

Muhamad Iksan was born in Bekasi on April 11, 1995. After graduation a vocational high school education in building engineering department continued his undergraduate civil engineering education at Mercu Buana University Jakarta in 2016 to 2020 by compiling the final project is Comparative study of stucture response isolated base and not isolated base on IHF school. Also active as a Engineering staff in building construction projects. 